\title{
MomentDergi
}

Hacettepe Üniversitesi İletişim Fakültesi Kültürel Çalışmalar Dergisi

2017, 4(1)

ISSN: 2148-970X.

\section{TEMA EDITÖRLERINDEN}

\section{ETNOGRAFIK DÜŞÜN}

“Etnografik saha çalışmasının tam ortasında olan iletişimcinin, tezinde yöntem olarak etnografiyi seçen sosyoloğun, etnografi ve estetik ilişkisini sorgulayan filozofun, dijital tekniklerle yeni bir etnografik anlatı peşinde olan sanatçının ya da etnografi dersine hazırlanan antropoloji kökenli bir akademisyenin-kısacası beşeri bilimlerin geniş yelpazesinde farklı temalar altında, farklı biçimlerde etnografiyle ilişkilenen herkesinbu tartışmaya dair söyleyecek bir sözü olması gerektiğini düşünüyoruz. Neden etnografi?" sorusuyla bir çağrıda bulunmuştuk. Moment Dergi'nin "etnografi" temalı sayısında, adeta çağrımızda öngördüğümüz yazılar ve yazarlarla dolu dolu bir içeriği sizlerin beğenisine sunuyoruz.

Tim Ingold'la yaptı̆̆ımız söyleşi son yıllarda alevlenen, heyecanı yüksek bir tartışmanın devamı gibi okunabilir. Ingold, antropoloji eğitiminin konvansiyonel bir eğitimden neden (ve mutlaka) farklı olması gerektiğini tartışıyor. Bilgi, zayıf ve bilgisiz olarak tasnif edilen karşısında bilgi sahibine belirli bir iktidar sağlayabilir, diyor Ingold; ancak tahayyülümüzün ufkunu genişletecek ve hayatın imkânlarını araştırabilecek türden bir bilgelik, buna niyetlenen bütün tarafların (öğrenci, katılımcı, araştırmacı, öğretim üyesi) yola birlikte çıkmasıyla mümkündür. Ingold'a göre böylesi bir bilgeliğe nereye varacağı baştan bilinen bir yolculukla erişilemez; antropolojinin zenginliği (ve etnografinin eksikliği) buradadır. Dileriz söyleşiden aldığımız keyfi ve duyduğumuz heyecanı okura yansıtmayı başarabiliriz. 
Etnografik araştırmaların İnternet mecrasına uygulanmasında öncü bir isim olan Daniel Miller da alan araştırmaları vesilesiyle Rusya ve İtalya arasında seyahat halindeyken bize zaman ayırdı ve söyleşi sorularımızı yanıtladı. Miller ile öncelikle henüz tamamladıkları, sosyal medya kullanımlarına odaklanan ve Türkiye'nin de dahil olduğu dokuz ülkede 15 ay süresince yürütülen "Why We Post" projesini konuştuk. Etnografik araştırmayı "iyi" ve "kötü" kılan unsurları sorduk. Gelecekteki projelerinden de söz ettik. Bir de Tim Ingold'un, burada Türkçe çevirisini yayınladığımız "Bu Kadar Etnografi Yeter!” makalesinde dikkat çektiği noktalara dair görüşünü aldık.

Sayının ilk makalesi John Postill'e ait. Medya antropolojisi/medya etnografisi alanında çalışanların yakından tanıdığı yazar, "Diyakronik Medya Etnografisi: Toplumsal Değişimden Fiilî Toplumsal Değişimlere" başlıklı çarpıcı yazısında, medya ve toplumsal değişim gibi çetin ve karmaşık bir ilişkiye etnografinin dürbününden bakıyor. Postill yazısında, medya ve toplumsal değişim meselesini "şimdiki zamandan" yola çıkarak incelemenin sınırlılıklarını vurgularken, değişimleri tarihsel bağlamı içinde kavrayabilecek bir etnografik perspektif önerisi geliştiriyor. Sahada gözlemlenebilir ve izi sürülebilir fiilî değişimleri etnografik olarak kavrayabilmek için yola çıkanlara Postill'in somut bir önerisi var: Diyakronik etnografi.

Postill'in makalesi üzerine, toplum medyası ve medya etnografisi alanlarındaki çalışmalarıyla tanınan Ece Algan'ın “Uzun Süreli Etnografinin Önemi Üzerine ve Postill'e Bir Yanıt" adlı eleştirel makalesi geliyor. Diyakronik etnografinin değerini ve katkılarını (dikkatimizi "şimdiki zaman"dan "etnografik geçmiş zaman"a çekmesi gibi) göz ardı etmeksizin Algan, etnografın alana yaptığı planlanmış ziyaretlerin öneminin altını çizmektedir. Toplumsal değişimlerde medyanın rolünü inceleyen mevcut (başarılı) etnografik çalışmalara ilişkin (kendi çalışması da dahil) Algan uzun süreli etnografik yaklaşımı önermektedir.

"Alevi-Olmayan Bir Araştırmacı Olarak Alevilik Üzerine Çalışmak: GöçMekânda Ama Evde Çok-Alanlı Etnografi" adlı makalesinde Besim Can Zırh etnografik saha çalışmalarında yaşanan kırılmalara değindikten sonra özdüşünümsel bir perspektiften kendi saha deneyimini okuyucu ile paylaşıyor. Çalışılan-ötekine ait "orası" ile çalışan-bene ait "burası" arasında kalın çizgiler çizilemeyeceği gibi "sahayı" verili bir mekân olarak düşünmenin de uygulamada olanaksız olduğunu kendi deneyimleri ile aktarıyor. Almanya (Berlin), İngiltere (Londra), ve Norveç'teki (Drammen) üç Alevi Kültür Merkezine odaklanan çok-alanlı etnografik araştırması için 
iki yıl bu mekânlarda ikamet eden Zırh, Alevi olmayan bir araştırmacı olarak deneyimlediklerini "evde antropoloji" tartışmalarına temaslarla anlatıyor.

Laurin Baumgardt'ın ilham verici yazısı “Yarım Kalmış Gelecekler: Güney Afrika'da Enformel Bir Yerleşim Biriminde Altyapı ve Özlemler Üzerine Etnografik Düşünceler", okuru yoksul kesimin yaşadığı Enkanini'de yürütülen bir saha çalışmasına davet ediyor. Etnografik saha çalışmasının yarım kalmaya mahkûm doğasının yanına, yarım kalan geleceklerinde daha iyi bir hayatın belirtilerini arayan ve ancak öyle ayakta kalabilen-insanların öyküsünü koyuyor Baumgardt. Makalesinde zengin saha gözlemlerine de yer veren yazar, yoksulluğun ve prekaryalaşmanın ivmelendiği bir dünyada "yarım kalmışlı̆̆ı" etnografik bir olanak olarak tartışıyor.

Çağdaş Ceyhan, Züleyha Özbaş-Anbarlı ve Nalan Ova'nın kaleme aldığı "Zamanın İzinde Kenti Deneyimlemek: Kent ve Bellek Üzerine Oto-Etnografik Bakışlar" makalesi Eskişehir ve Ankara üzerine üç yazarın deneyim ve yaşantılarını anlatı haline getirdiği bir oto-etnografi çalışması. Anımsamanın politikliği vurgusuyla bu iki kente dair kendi geçmişlerinin belleklerindeki izlerini ve bugünkü izlenimlerini bir araya getiren yazarlar gündelik hayat, sokak ve siyasete temas ederek hem hislerini paylaşıyor hem de, kendi tabirleriyle, bir yüzleşme deneyimi sunuyorlar.

“Çoklu Türler Etnografisi: Yüz Yüze Bir Araştırma İmkânı Üzerine Düşünceler" makalesinde Ezgi Burgan, insan merkezci olmayan bir etnografik araştırmanın teorik ve metodolojik imkanını tartışmaya açıyor. Bir özne olarak hayvanları şeyleştirmeden, onların kendilerine özgü dünyalarını görmeye çabalayan bir etnografik yaklaşım örnekler üzerinden sergilenirken yaşanabilir hayatlar, dil ve temsil, alt-üst edici pratikler, doğa-kültür ayrımının kırılması mevzuları da ele alınıyor. Farklı türler arasındaki karşılaşmalara eleştirel ve ilişkisel perspektifle bakmanın yanı sıra farklı egemenlik biçimleri arasındaki kesişimi de tartışmaya dahil eden çoklu türler etnografisi alanında önde gelen isimler ve çalışmalara da değiniyor Burgan.

Bir diğer yazarımız Oya Morva odaklandığı teorik ve metodolojik kesişimi yazısının başlı̆̆ında özetliyor: “Chicago Sosyoloji Okulu'nun Etnografik Mirasını Yeniden Okumak: Dijital Etnografi Çağında Sembolik Etkileşimcilik". Chicago Okulu'nun etnografları 20. yüzyılın kentli bireyini anlamak isteyen toplum bilimcilere sokağın sırrını öğretti: Gündelik olanın müphem doğası, yüz yüze iletişimin karmaşık ve kaygan yapısı kentin sokaklarında ete kemiğe bürünüyordu çünkü. Kuruluşundan yüz yıl sonra Chicago Okulu'nun izini süren Morva yazısında, tıpkı dün olduğu gibi 
dijital bir gündelik hayatı ve bu hayatın dijital sokak kültürünü anlamak için de Okul'un bugünkü "mezunlarını" takip etmemizi salık veriyor.

Etnograf, sahanın gözlemle başlayan ve biten bir ilişkiler coğrafyasından ibaret olmadığını bilir. Saha, her şeyden önce bir tahayyüldür; sorumluluk üreten, iktidar ilişkileriyle ve etik sınırlarla çevrili bir tahayyül. Saha çalışması boyunca bu tahayyülü değişime uğratan, derinleştiren, güven üreten karşılaşmalar kadar onu sınırlayan ve etik açıdan problemli bir zemine taşıyan gerilimler de yaşanır. Bu sayıdaki tematik yazıların sonuncusu Başak Can'ın “Gündelik Hayat, İktidar İlişkileri ve Etik Kodların Kesişiminde Etnografik Araştırma" başlıklı yazısı işte bu son derece önemli gerilime odaklanıyor. Can, etik ilkelere sadakat, sahanın mahremiyeti, hakikati arama özgürlüğü gibi yaşamsal meselelerde iktidarın (devletin) gözü karşısında araştırmacının kırılgan konumuna işaret ediyor; Türkiye bağlamından kişisel deneyimlerle ve gözlemlerle bu kırılganlığı tartışmaya açıyor.

Etnografi sayımızda zengin saha deneyimine sahip dört yazarın değinileri de bulunuyor. Değinilerden ilki Tim Ingold'un HAU-Journal of Ethnographic Theory dergisinde 2014 yılında yayımlanan Bu Kadar Etnografi Yeter! başlıklı yazısı. Ingold'un bu sayıdaki söyleşisini Beren Kandemir'in Türkçeleştirdiği bu son derece kışkırtıcı ve zihin açıcı yazısıyla birlikte okumanızı öneriyoruz.

Tayfun Atay'ın 1996'da yayınlanan "Sosyal Antropolojide Yöntem ve Etik Sorunu: 'Klasik Etnografiden Diyalojik Etnografiye Doğru' " makalesini burada tekrar okuyucuyla buluşturmak istedik. İlk kez 4. Ulusal Sosyal Bilimler Kongresi'nin İnsan Toplum Bilim adıyla basılan bildiri kitabında yayımlanan bu makale klasik antropolojiden düşünümselliğin ön plana çıktığı, diyalojik bir antropolojiye gidilen yolda sosyal antropolojinin temel ve kritik tartışmalarını masaya yatırıyor.

Türkiye'de iletişim çalışmaları alanında nitel yöntemin ve özellikle de etnografinin benimsenmesinde büyük emeği olan Asker Kartarı'nın “Nitel Düşünce ve Etnografi: Etnografik Yönteme Düşünsel Bir Yaklaşım” adlı yazısı niteliksel düşüncenin ne olduğunu, nereden kaynaklandığını ve etnografi ile olan ilişkisini ele alıyor. Kartarı farklı disiplinlerden ve yaklaşımlardan örneklerle niteliksel araştırma yönteminin tarihsel ve güncel izleğini sunmakla birlikte etnografinin bu izlek içerisindeki yerini de irdeliyor.

Bu sayıda tema dışı iki yazımız var: "Tahminlerden Geriye Kalanlar Üzerine: Akademide İletişim Felsefesini Aramak" başlıklı yazısında Burcu Canar iletişim felsefesini sorunsallaştıran uzun soluklu, karşılaştırmalı (Amerika Birleşik Devletleri ve 
Türkiye) saha araştırmasının ilk tespitlerini paylaşıyor okurla. İletişim felsefesinin yaklaştıkça netliğini yitiren doğasına işaret eden ve dikkatini akademia'ya çeviren yazar bu makalesinde, felsefe, iletişim ve medya çalışmaları gibi bölümlerden akademisyenlerin tanıklığında ve zengin gözlemler eşliğinde bu alanda yürütülecek çalışmalar için yeni bir yöntemin (Ulysses Vakası) olanaklarını araştırıyor. Yazı böyle bir yöntem önerisinin manifestosu niteliğinde.

“Mekân ve Kolektif Bellek: Sivas Katliamı ve Madımak Oteli" makalesiyle Ozan Çavdar, Sivas Katliamı'nda yakınları öldürülen kişilerin Madımak Oteli'ne dair deneyimlerinin izini sürüyor. Madımak Oteli önünde yapılan anmalara katılarak gözlemler yapan ve bu sahada derinlemesine görüşmeler gerçekleştiren Çavdar, bireyin mekânla kurduğu ilişkiyi bellek ve ritüel çerçevesinde ele alıyor. Travma mekânları, kolektif bellek ve belleğin mekânsal kuruluşu bağlamında Sivas'ta yakınlarını kaybeden kişilerden ve ailelerden oluşan grupların sesine de işitilme imkânı veriyor makale.

Kitap takdimi bölümümüzde Z. Nilüfer Nahya ve Rabia Harmanşah birlikte derledikleri yeni çalışmaları Etnografik Hikâyeler: Türkiye'de Alan Araştırması Deneyimleri (Metis, 2017) kitabının serüvenini paylaşıyorlar. Yazarlar etnografların yakından bildiği ancak yazım aşamasında genellikle çerçevenin dışına itmek durumunda kaldıkları "ayrıntıları" yeniden hak ettikleri yere, etnografik hikâyenin merkezine çağırıyor. Bu son derece değerli çağrının katkısı saha deneyiminin giderek önemsizleştirildiği ve tali kılındığı bir etnografi dalgasının gölgesinde daha da belirginleşiyor.

Kitap değerlendirme bölümümüzde üç yazı bulunuyor. İlki, Aksu Bora'nın “Oyunbozan Feminist: Sara Ahmed" başlıklı yazısı. Ahmed'in son dönemde Türkçeye çevrilen Duyguların Kültürel Politikası ile Mutluluk Vaadi kitaplarından yola çıkan Bora, sayfalar ilerledikçe okuru Sara Ahmed külliyatının temel derdine, oradan da duygular sosyolojisinin ufkuna uzanan zihin açıcı, öğretici bir tartışmaya davet ediyor. Ahmed'in yazılarında işlediği meseleler ile hayatta dert edindikleri arasındaki paralellikleri not eden Bora, kişisel tecrübeyi bilginin-ama o bilgiyle yüzleşirken ihtiyaç duyacağımız cesaretin de-kaynağı olarak tarif eden fenomenolojik yaklaşımın kristalleşmiş örneklerini arayanlara Ahmed'in kitaplarını öneriyor.

Mutlu Binark "Kırsal Çin'de Sosyal Medya Kullanımı: Ağlaşmış Bireysellikler ve Ahlaki Çerçevelerin Yeniden İnşası Arasındaki Gergin Hat" yazısında Tom McDonald'ın Social Media in Rural China: Social networks and moral frameworks kitab1 hakkında yazıyor. McDonald'ın kitabının konusu olan Çin'in Anshan kasabasında gerçekleştirdiği 15 aylık etnografik araştırma bizim bu sayıda söyleşisine de yer 
verdiğimiz Daniel Miller'in “Why We Post" genel başlığıyla yürüttüğü saha çalışmasının bir parçası. Binark, McDonald'ın projesini sosyal medyaya yaklaşımı ve metodolojisi açısından detaylı olarak değerlendiriyor ve sosyal medya üzerine etnografik çalışma yürütecek olan araştırmacılara kitabı tavsiye ediyor.

"İmgeleri Okumak: Etnografi ve Sanat" başlıklı yazısında Cem Koray Olgun, Nermin Saybaşılı'nın "Sanat Sahada: Görsel Kültür Çalışmalarında Etnografik Bilgi" kitabını değerlendiriyor. Kitaptaki kuramsal ve metodolojik tartışmalardan ve Saybaşılı'nın sanatı etnografik bir nesne olarak görmesinden hareketle Olgun sanat, sanatçı ve etnograf ilişkisine değiniyor. Ayrıca Olgun kitapta bazı eksik bulduğu tartışmalara işaret etmeyi de ihmal etmiyor.

Son olarak, Emel Uzun ve Göze Orhon 11-12 Mayıs tarihlerinde “Utopia'nın 500. Yılında Politika ile Arzunun Kesiştiği Yer: Ütopyalar” başlı̆̆ıyla Mülkiyeliler Birliği'nde gerçekleştirilen III. Siyasal Psikoloji Konferansı'nı Moment için yazdılar.

Hazırlamaktan büyük keyif aldığımız Etnografi sayımızı sizlerle paylaşırken, etnografiye dair kapsamlı tartışmaların ülkemizde de çeşitli platformlarda artarak devam etmesini temenni ediyoruz. Ayrıca Dergi hazırlık sürecinde bizden "yoğun" ilgilerini esirgemeyen sevgili Gaia ("nerdeyse" beş yaşında) ve Sarp'a (17 aylık) müteşekkiriz. Söyleşimizi gerçekleştirdiğimiz Tim Ingold ve Daniel Miller başta olmak üzere, bu sayıya katkı sunan, emek veren yazarlara, hakemlere ve tüm dergi ekibine teşekkür ederiz. İyi okumalar!

\section{Emek Çaylı Rahte}

\section{Hakan Ergül}

